\title{
A first Canadian and three new Québec records of Cicadellidae (Hemiptera) in grapevine (Vitaceae): potential virus vectors - CORRIGENDUM
}

\author{
I.E. Ben Moussa, P. Lemoyne, C. Beaulieu, J. Kits, and M.L. Fall \\ https://doi.org/10.4039/tce.2020.53. Published by Cambridge University Press, 13 October 2020
}

In the original online version of the article by Ben Moussa et al. (2020) in the December 2020 issue of The Canadian Entomologist, the title was incorrectly set as "A first Canadian and three new Québec records of Cicadellidae (Hemiptera) in grapevine (Vitaceae): potentials virus vectors." The title has been corrected in the online version of the article and the table of contents for the issue.

\section{Reference}

Ben Moussa, I.E., Lemoyne, P., Beaulieu, C., Kits, J. and Fall, M.L. 2020. A first Canadian and three new Québec records of Cicadellidae (Hemiptera) in grapevine (Vitaceae): potential virus vectors. The Canadian Entomologist, 152: 797-801. https://doi.org/10.4039/tce.2020.53.

\footnotetext{
Cite this article: Ben Moussa, I.E., Lemoyne, P., Beaulieu, C., Kits, J., and Fall, M.L. 2021. A first Canadian and three new Québec records of Cicadellidae (Hemiptera) in grapevine (Vitaceae): potential virus vectors - CORRIGENDUM. The Canadian Entomologist, 153: 257. https://doi.org/10.4039/tce.2020.79.
} 